OPEN ACCESS

Edited by:

Tao Wang,

Zhejiang University, China

Reviewed by:

Menglian Zheng,

Zhejiang University, China

Robert J. Braun,

Colorado School of Mines,

United States

*Correspondence:

Manuel Bailera

mbailera@unizar.es

Specialty section:

This article was submitted to

Carbon Capture, Storage, and Utilization

a section of the journa

Frontiers in Energy Research

Received: 31 March 2020

Accepted: 16 June 2020

Published: 14 July 2020

Citation:

Bailera M, Peña B, Lisbona P and Romeo LM (2020) Improved Flexibility and Economics of Combined Cycles by Power to Gas.

Front. Energy Res. 8:151. doi: 10.3389/fenrg.2020.00151

\section{Improved Flexibility and Economics of Combined Cycles by Power to Gas}

\author{
Manuel Bailera ${ }^{1 *}$, Begoña Peña ${ }^{1}$, Pilar Lisbona ${ }^{2}$ and Luis M. Romeo ${ }^{1}$ \\ ${ }^{1}$ Escuela de Ingeniería y Arquitectura, Universidad de Zaragoza, Zaragoza, Spain, ${ }^{2}$ Fundación Agencia Aragonesa Para la \\ Investigación y el Desarrollo (ARAID), Zaragoza, Spain
}

Massive penetration of renewable energy in the energy systems is required to comply with existing $\mathrm{CO}_{2}$ regulations. Considering current power pools, large shares of renewable energy sources imply strong efficiency and economic penalties in fossil fuel power plants as they are mainly operated to regulate the system and constant shutdowns are expected. Under this framework, the integration of a combined cycle power plant (CCPP) with an energy storage technology such as power to gas (PtG) is proposed to virtually reduce its minimum complaint load through the diversion of instantaneous excess electricity. Power to gas produces hydrogen through water electrolysis, which is later combined with $\mathrm{CO}_{2}$ to produce methane. The main novelty of this study relies in the improved flexibility and economics of combined cycles by means of using power to gas as a tool to reduce the minimum complaint load. The principal objective of the study is the quantification of cost reduction under different scenarios of shutdowns and conventional start-ups. The case study analyses a combined cycle of $400 \mathrm{MW}_{\mathrm{e}}$ gross power with a minimum complaint load of $30 \%$ that can be virtually reduced to $20 \%$ by means of a $40-\mathrm{MW}_{\mathrm{e}}$ power-to-gas plant. Eight scenarios are defined to compare the reference case of conventional operation under hot, warm, and cold start-ups with power-to-gas-assisted operation. Additionally, PtG-assisted operation scenarios are analyzed with different loads (30-50-70\%). These scenarios also include the consideration of a temporary peak of demand occurring in a period in which dispatch is below the minimum complaint load. Under this situation, the response time of conventional plants is very limited, while PtG-assisted CCPP can rapidly satisfy the peak. The techno-economic model quantifies the required fuel, gross and net power, and emissions as well as total costs and incomes under each scenario and net differential profit in an hourly basis. The analysis of the obtained results does not recommend the operation of the PtG-assisted CCPP at minimum complaint load for hot, warm, or cold start-ups. However, important marginal profits are achieved with the proposed system for part-loads operation over 50\% for every sort of start-up, avoiding shutdowns and extending the capacity factor.

Keywords: flexibility, energy storage, power to gas, combined cycle, synthetic methane, $\mathrm{CO}_{2}$ utilization

\footnotetext{
Abbreviations: CCPP, combined cycle power plants; FFPP, fossil fuel power plants; FSNL, full speed no load; FL, full load; MCL, minimum complaint load; NSNL, no speed no load; O\&M, operation and maintenance; PtG, power to gas; REF, reference case; RES, renewable energy sources; VMCL, virtual minimum complaint load.
} 


\section{INTRODUCTION}

Aiming to reduce the greenhouse gas emissions below $40 \%$ of the 1990 levels (Paris Agreement of 2015) (United Nations Framework Convention on Climate Change [UNFCCC], 2015), the European Directive 2018/2001 promotes reaching 32\% share of renewable energy sources (RES) by 2030 (European Commission, 2018). Moreover, RES share in European electricity production is expected to increase to $53 \%$ by 2050 (Capros et al., 2016). However, the transition toward a decarbonized society implies large amounts of variable RES in the energy system, wherein the balance between power generation and demand is difficult (Bailera and Lisbona, 2018; Lisbona et al., 2018). The problem of optimal dispatch and its connection with renewables or natural gas grids is being profusely analyzed in literature (Chen et al., 2018; He et al., 2018, 2020; Wang et al., 2019; Naval et al., 2020).

Traditionally, fossil-based regulation kept the frequency and the voltage of the grid within a stable range. Nowadays, power pools favor RES to the detriment of fossil-based electricity. However, generators and system operators control just $5-10 \%$ of the dispatch in RES power plants (the level of control in Spain is about 5\%, in Sweden 6\%, and in Germany 7\%) (Pierre et al., 2011). Therefore, fossil fuel power plants (FFPP) are compelled to perform many start-ups, shutdowns, and load variations to meet demand. These cycling processes deteriorate the equipment, drop the efficiency, worsen specific $\mathrm{CO}_{2}$ emissions, and increase the costs (Gilbert and Sovacool, 2017).

The implications of this issue have been analyzed in literature for energy systems worldwide. In northeastern China, Yin et al. (2017) studied the benefits of curtailing some wind power. They found that the overall income is optimized when the daily average wind curtailment is $2.17 \%$. Despite curtailing some RES, the $\mathrm{CO}_{2}$ emissions do not increase with respect to a scenario in which wind power is completely integrated in the grid. The extra amount of $\mathrm{CO}_{2}$ that would be saved using the surplus wind power is canceled out by the high specific emissions of peak regulation in FFPP.

In Europe, de Groot et al. (2017) analyzed how the share of variable renewable technologies (VRE) influences on the performance of FFPP for different scenarios from 2005 to 2014 (de Groot et al., 2017). When renewable penetration is higher than $15 \%$, they found that the yearly average efficiency of the combined cycle power plant (CCPP) drops by 20 points since fullload operating hours diminishes by $53 \%$. Besides that, Van den Bergh and Delarue (2015) state that the implications of the overall cycling process (i.e., direct start, indirect start, outages, ramping, and efficiency decrease) are overlooked by system operators as they consider only the direct start. If the system operator considered total cycling costs when developing the optimal schedule for 25-40\% VRE penetrations, the annual cycling costs of power plants could be reduced at $40 \%$.

In western United States, Lew et al. (2013) studied scenarios with wind and solar penetrations up to $33 \%$. They showed that the increment of emissions associated to cycling processes $(+0.2 \%$ of total $\mathrm{CO}_{2}$ emissions) has a small impact on the $\mathrm{CO}_{2}$ saved because of the curtailment of fossil fuels $\left(-34 \%\right.$ of total $\mathrm{CO}_{2}$ emissions). However, the cycling cost may increase to 1.28 US\$ per MWh, which is not negligible in the context of reduced generation and revenue.

Actually, incomes from electricity will not cover production costs even if enough flexibility is achieved (Sjoerd Brouwer et al., 2015). Hentschel et al. (2016) showed that the profits barely change with faster ramp rates in combined cycles. Only the reduction of the minimum complaint load (MCL), the minimum load at which the plant can reliably operate before being disconnected out of the grid, may lead to relevant savings, thanks to avoiding the curtailment of incomes (Hentschel et al., 2016; Romeo et al., 2018). Under this framework, the authors propose to use power to gas $(\mathrm{PtG})$ technology to virtually reduce the MCL of a given combined cycle. Instead of shutting down the combined cycle, the electricity production that exceeds demand may be diverted to the PtG energy storage. A similar concept was previously assessed by the authors, in which PtG displaces nuclear power to avoid part-load operation in coal-fired power plants (the average annual efficiency of the FFPP increased from 33.2 to $35.2 \%$ ) (Bailera et al., 2019c).

Power to gas aggregates different technologies through which electricity is chemically stored in the form of gaseous or liquid chemicals and fuels (Andika et al., 2018; Brynolf et al., 2018; Buttler and Spliethoff, 2018; Allman et al., 2019; Anghilante et al., 2019). Among them, power to methane is one of the most promising long-term storage technologies for the versatility regarding applications and the use of current gas network infrastructures (Götz et al., 2015; Bailera and Lisbona, 2018; Eveloy and Gebreegziabher, 2018; Lewandowska-Bernat and Desideri, 2018; Wulf et al., 2018; Thema et al., 2019). These technologies not only will play an important role in decarbonization of the industry (Baier et al., 2018; Cormos et al., 2018; Di Salvo and Wei, 2019; Chauvy et al., 2020; Rosenfeld et al., 2020), transport (Schemme et al., 2017; Colbertaldo et al., 2019), and building (Bailera et al., 2019b) but also will be needed to balance the power generation with demand under high penetration of variable renewable energies (Bailera and Lisbona, 2018; Eveloy and Gebreegziabher, 2018; Wulf et al., 2018).

In the present work, power to gas uses the part of electricity that the CCPP cannot sell at the moment to produce hydrogen through water electrolysis. Then, this hydrogen is combined with $\mathrm{CO}_{2}$ to produce methane through methanation (Gahleitner, 2013; Giglio et al., 2015; Götz et al., 2015; Jensen et al., 2015; Vandewalle et al., 2015; Bailera et al., 2017a,b; Becker et al., 2019). Several options have been proposed in literature for the supply of $\mathrm{CO}_{2}$. Biogas is an attractive carbon source because it avoids the carbon capture stage and methanation heat could be used in the digestion process (Angelidaki et al., 2018; Anghilante et al., 2019). Nevertheless, the most common and simplest integration that directly uses $\mathrm{CO}_{2}$ from carbon capture in the combined cycle is considered as more realistic for the application investigated. Besides that, in this work, the synthetic natural gas coming from the PtG process is used as fuel for the combined cycle itself to reduce the operating cost.

The novelty of this paper underlies in the improved flexibility and economics of combined cycles by using power to gas as method to reduce the minimum complaint load. The objective 

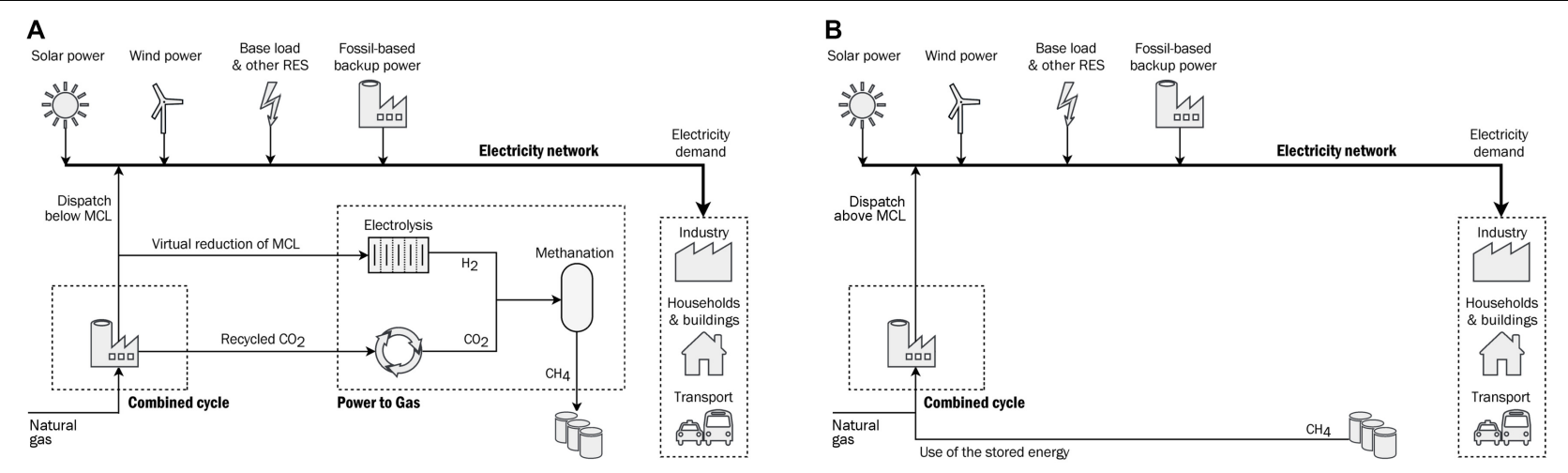

FIGURE 1 | Integration of power to gas and combined cycle power plant in the energy system: (A) Dispatch below minimum complaint load (MCL) diverting surplus electricity to power to gas. (B) Dispatch above MCL using stored energy.

is to compare and quantify this proposal with different scenarios of shutdowns and conventional start-ups.

\section{CASE STUDY}

In this study, we assess a combined cycle of $400 \mathrm{MW}_{\mathrm{e}}$ gross power. The auxiliaries of the plant consume $2.5 \%$ of this power output. The minimum complaint load is $30 \%$ (NalbandianSugden, 2016), but it can be virtually reduced to $20 \%$ by using PtG. This power-to-gas plant manages up to $40 \mathrm{MW}_{\mathrm{e}}$ (i.e., $10 \%$ of the gross power of the CCPP). The overall efficiency of the energy storage is assumed constant at 60\% (power to methane), accounting for polymer electrolyte membrane electrolysis (75\% higher heating value, HHV) (Matute et al., 2019) and methanation (80\% HHV) (Bailera et al., 2019a). Figure 1 illustrates the system under study.

\section{Operation of Combined Cycles}

A power plant must follow different steps to modify its operating load. These processes depend on the start and end points between which the load is varied. This section describes the main cycling processes taken into account for the study and establishes some important assumptions during the operation of the combined cycle (Gonzalez-Salazar et al., 2018).

- Process 1 - start-up: The first process is the start-up of the plant. The turbine, which initially is stopped ("no speed, no load"), increases its speed up to synchronize the generator with the grid frequency ("full speed, no load"). Then, the load raises to the minimum complaint loads that fulfill safety and emission requirements. From this point upwards, the combined cycle may start generating power (Figure 2). The duration of the start-up varies, depending on how long the power plant has been stopped. Standby periods are classified in hot start ( $0-12 \mathrm{~h}$ offline), warm start (12-48 h offline), and cold start ( $>48 \mathrm{~h}$ offline) (Smith et al., 2020). A standby of $6 \mathrm{~h}$ is considered for hot start, $24 \mathrm{~h}$ for warm start, and $48 \mathrm{~h}$ for cold start. We have also assumed 1$\mathrm{h}$ period to full load for hot start, 2-h period to full load for warm start, and 3-h period to full load for cold start (Smith et al., 2020). Besides that, during start-up, the power output is constrained to the last one-third of the time, at a load equal to the MCL.

- Process 2 - ramping up/down: After start-up, the combined cycle can modify its load to any point between MCL and full load (FL) to satisfy demand. We assume $6 \% \mathrm{FL} / \mathrm{min}$ ramp rate (Gonzalez-Salazar et al., 2018), so passing from MCL to FL takes around 10-15 min. This duration is much shorter than for other processes and therefore neglected in the economic analysis.

- Process 3 - full load: Process 3 represents nominal operation, at which the efficiency of the power plant is the highest and the specific emissions are the lowest.

- Process 4 - minimum load: Process 4 describes the operation at minimum complaint load. This point has the lowest efficiency and the highest specific emissions.

- Process 5 - shutdown: When dispatch is no longer required, the combined cycle has to shut down. The load diminishes at $6 \% \mathrm{FL} / \mathrm{min}$, so it takes $15-20 \mathrm{~min}$ to stop the plant when operating at full load. As simplification, we have also neglected the duration of this process for economic analysis.

- Process 6 - no operation: After shutdown, the combined cycle remains out of operation. There are no incomes throughout this period, so its duration should be minimized. Power to gas will help in avoiding this situation whenever demand is between 30\% (MCL) and $20 \%$ of full load.

\section{METHODOLOGY}

The methodology section covers the scenarios of operation that are analyzed in this study and the techno-economical models used to characterize them. For each hour of the studied period, the load is assumed depending on the scenario described below. With the load, it is possible to calculate the net power production and input energy required. Hourly costs are calculated with this data. When power to gas is running, its power is subtracted from 


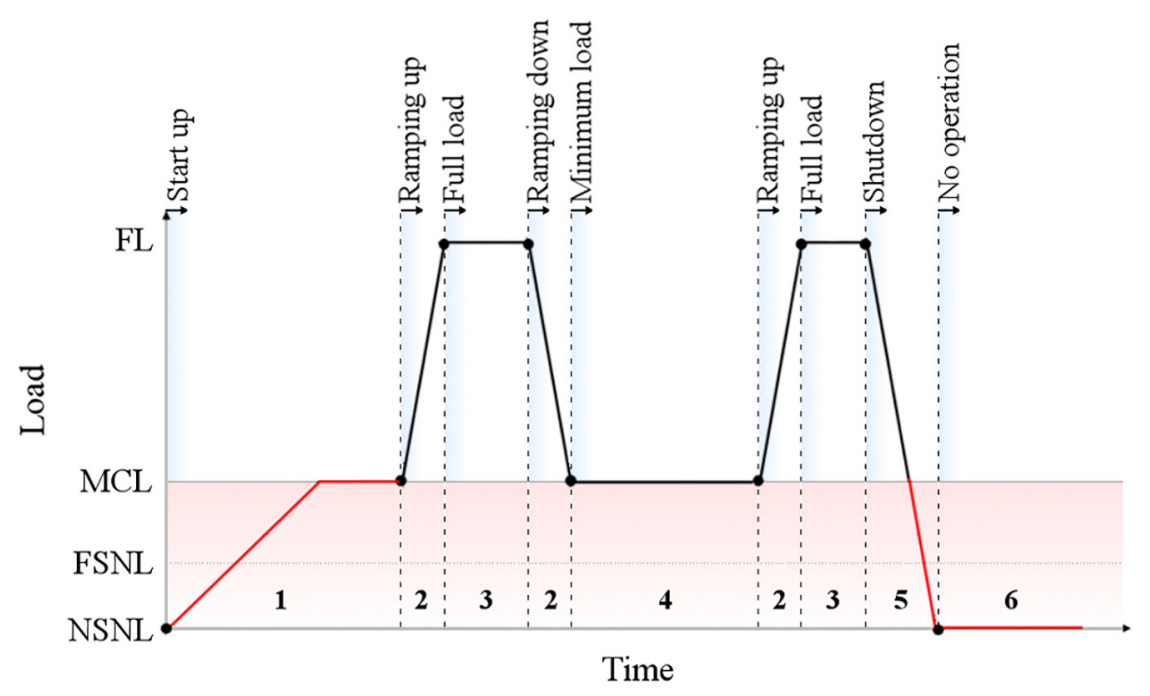

FIGURE 2 | Types of process during the operation of a combined cycle.

net power and natural gas is stored to be used in the full-load hours. The addition of hourly cost and incomes for the number of operational hours of the period and its comparison with the reference case are used as key variables of the work.

\section{Scenarios}

The definition of these scenarios allows the comparison of the conventional operation of combined cycles with the PtGassisted operation of the hybrid system for situations in which electricity demand falls below the minimum complaint load ( $<30 \% \mathrm{FL}$, i.e., $<120 \mathrm{MW}_{\mathrm{e}}$ ). This situation may be due to an increase in RES production or simply a demand reduction. In the first case, it is supposed that there is no RES curtailment. Conventional CCPP have to shut down and follow a "no operation" period in which there are no incomes. On the other side, power-to-gas hybridization avoids shutdown if demand is still above $20 \%$ FL. The hybrid CCPP keeps operating at MCL, dispatching the $20 \% \mathrm{FL}$ demanded by the grid $\left(80 \mathrm{MW}_{\mathrm{e}}\right)$ and diverting the remaining $10 \% \mathrm{FL}\left(40 \mathrm{MW}_{\mathrm{e}}\right)$ to the power-to-gas system (Figure 3). It has been assumed that the electrolyzers operation is on or off and there is no part-load operation for this equipment. Moreover, the time spent to get back to full-load operation is shorter in the hybrid system since there is no start-up.

The outage duration under conventional CCPP conditions determines the type of start-up (hot, warm, or cold start). According to that, eight scenarios are defined and grouped to compare the reference case of conventional operation with situations that take advantage of the power-to-gas storage system (Table 1). The time framework within which the analysis is performed (total time of scenario) is fixed in each group to compare equivalent situations. Additionally, scenarios 2, 4, and 7, corresponding to $\mathrm{PtG}$-assisted operation, are analyzed with different loads $(30,50$, and $70 \%)$. These scenarios are realistic as, although MCL is the typical scenario, it is also usual that the operator asks for increasing loads in the remaining (nonstopped) installations to meet the demand.

A third type of operation is analyzed in scenarios 5 and 8: a temporary peak of demand taking place in the middle of a dispatch that is below the minimum complaint load is considered. Under this situation, the response time of conventional CCPP is very limited since the plant should carry out a warm or cold startup (Figure 4). Contrarily, the PtG-assisted CCPP is able to satisfy the peak rapidly since the plant keeps working at the virtual MCL. In the quantitative analysis, electricity is diverted to PtG until full-load operation is achieved, as depicted in Figure 4.

\section{Efficiency Penalty and Emissions}

The technical model quantifies the fuel required, the gross/net power produced, and the emissions, by energy and mass balances, in an hourly basis. All these values depend on the load at which the plant operates due to efficiency changes. It should be noted that despite the virtual MCL of the PtG-assisted CCPP being $20 \%$, the actual load at which the plant operates in those situations is $30 \%$.

Different equations to describe the variation in efficiency as a function of partial load can be found in literature (Sjoerd Brouwer et al., 2015). In combined cycles, a decrease of eight to 16 percentage points from full load to MCL is typical (Van den Bergh and Delarue, 2015; de Groot et al., 2017). For this study, we adopt Equation 1, a polynomic curve for the gross efficiency, which is adjusted to a set of different data by de Groot et al. (2017).

$$
\eta_{\text {gross }}=-0.272 \cdot \text { load }^{2}+0.5742 \cdot \text { load }+0.282
$$

Data calculated from Equation (1), for the $400 \mathrm{MW}_{\mathrm{e}} \mathrm{CCPP}$ of this study, are presented in Table 2. We assume that the specific $\mathrm{CO}_{2}$ emission at full load is $337.7 \mathrm{~kg} / \mathrm{MWh}$. As thermal efficiency worsen, these emissions increase to $459.0 \mathrm{~kg} / \mathrm{MWh}$ for the minimum complaint load (30\%). 

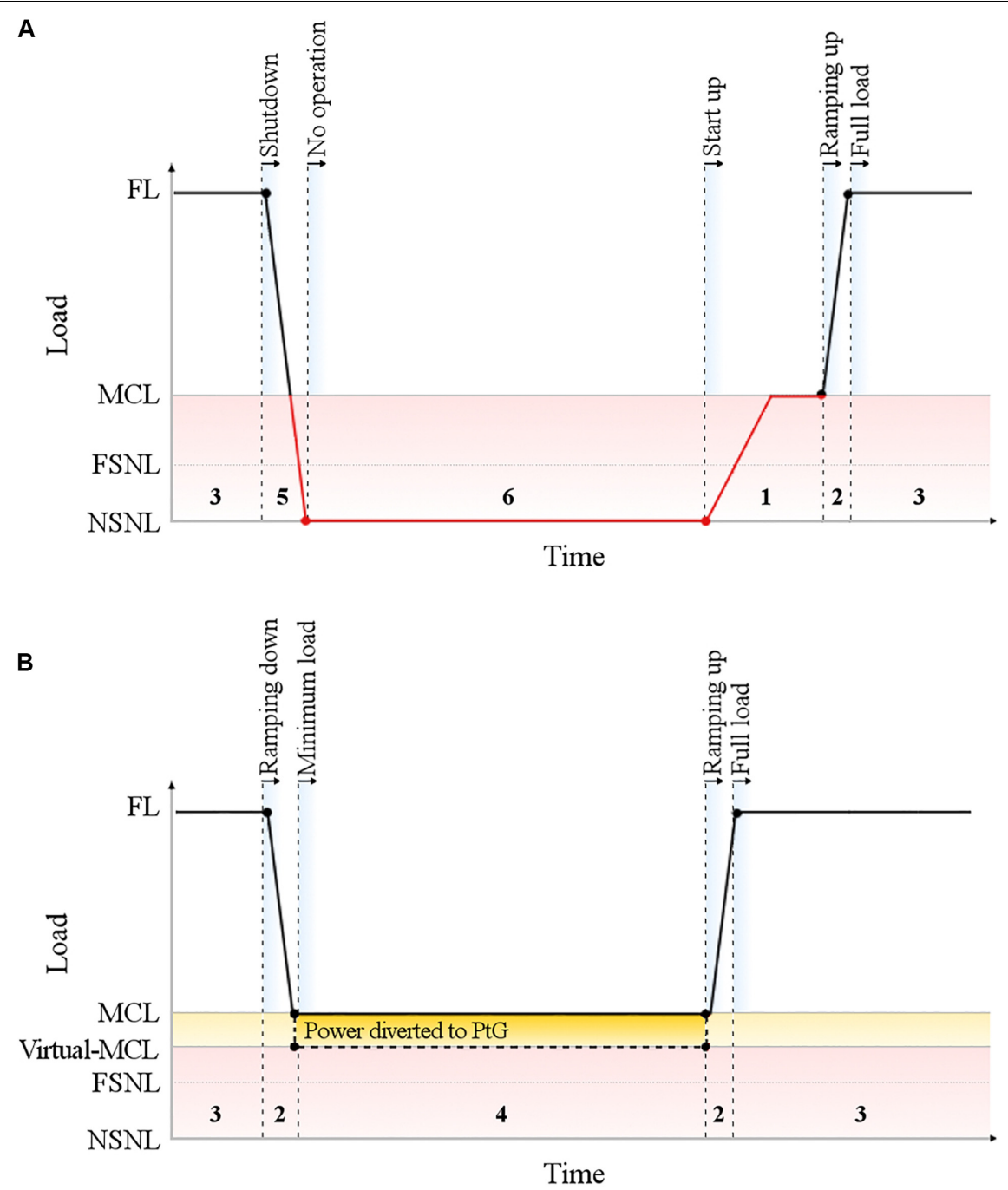

FIGURE 3 | Comparison between (A) conventional combined cycle power plant (CCPP) and (B) PtG-assisted CCPP while following an electric demand that falls below the minimum complaint load.

TABLE 1 | Selected scenarios for this work and types of operation.

\begin{tabular}{|c|c|c|c|c|c|c|c|c|}
\hline Scenario & 1 & 2 & 3 & 4 & 5 & 6 & 7 & 8 \\
\hline Outage (h) & \multicolumn{2}{|c|}{6} & \multicolumn{3}{|c|}{24} & \multicolumn{3}{|c|}{48} \\
\hline Start-up (h) & \multicolumn{2}{|c|}{$1 \mathrm{~h}$ (hot) } & \multicolumn{3}{|c|}{$2 \mathrm{~h}$ (warm) } & \multicolumn{3}{|c|}{$3 \mathrm{~h}(\mathrm{cold})$} \\
\hline Analyzed time framework (h) & \multicolumn{2}{|c|}{24} & \multicolumn{3}{|c|}{48} & \multicolumn{3}{|c|}{96} \\
\hline \multicolumn{9}{|l|}{ Comparison of: } \\
\hline Conventional operation & $\checkmark$ & $x$ & $\checkmark$ & $x$ & $x$ & $\checkmark$ & $x$ & $x$ \\
\hline PtG-assisted operation & $x$ & $\checkmark$ & $x$ & $\checkmark$ & $\checkmark$ & $x$ & $\checkmark$ & $\checkmark$ \\
\hline $\begin{array}{l}\text { PtG-assisted operation + } \\
\text { load peak (peak duration) }\end{array}$ & $x$ & $x$ & $x$ & $x$ & $\begin{array}{c}\checkmark \\
(12 h)^{\star}\end{array}$ & $x$ & $x$ & $\begin{array}{c}\checkmark \\
(24 h)^{*}\end{array}$ \\
\hline
\end{tabular}

*Duration of the peak of demand.

\section{Economics}

In the economic model, we calculate the total cost (Equation 2) and incomes (Equation 3) of each type of operation, and then we compared them through the net differential profit. The model is defined in an hourly basis (e.g., hourly OPEX, CAPEX,
$\mathrm{CO}_{2}$ taxes, and fuel cost), as for the technical model. Besides that, for the specific situation in which the PtG-assisted CCPP works at the virtual MCL, we consider that the plant operating costs correspond to $30 \%$ part load (actual MCL), but the sale of electricity is limited to $20 \%$ of the power (virtual MCL).

$$
\text { Total cost }\left[\begin{array}{l}
\mathrm{C} \\
\mathrm{h}
\end{array}\right]=\operatorname{OPEX}\left[\begin{array}{l}
\mathrm{C} \\
\mathrm{h}
\end{array}\right]+\operatorname{CAPEX}\left[\begin{array}{l}
\mathrm{C} \\
\bar{h}
\end{array}\right]
$$

Incomes $[€]$

$=$ net electricity production $[\mathrm{kWh}] \cdot$ electricity price $\left[\frac{\mathrm{C}}{\mathrm{kWh}}\right]$

The CAPEX is assumed as $800 € / \mathrm{kW}_{\mathrm{e}}$ for the conventional CCPP (Nalbandian-Sugden, 2016) and 2,600 €/ $\mathrm{kW}_{\mathrm{e}}$ for the power-to-gas plant (Schiebahn et al., 2015; Lee et al., 2019). This value is a conservative figure that includes the sum of 


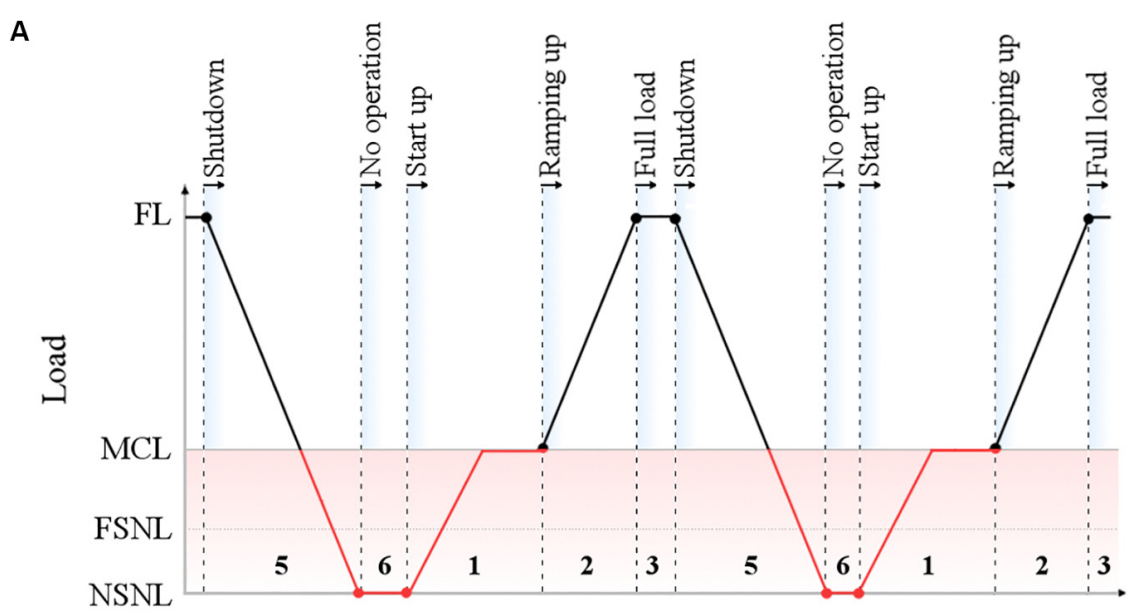

Time

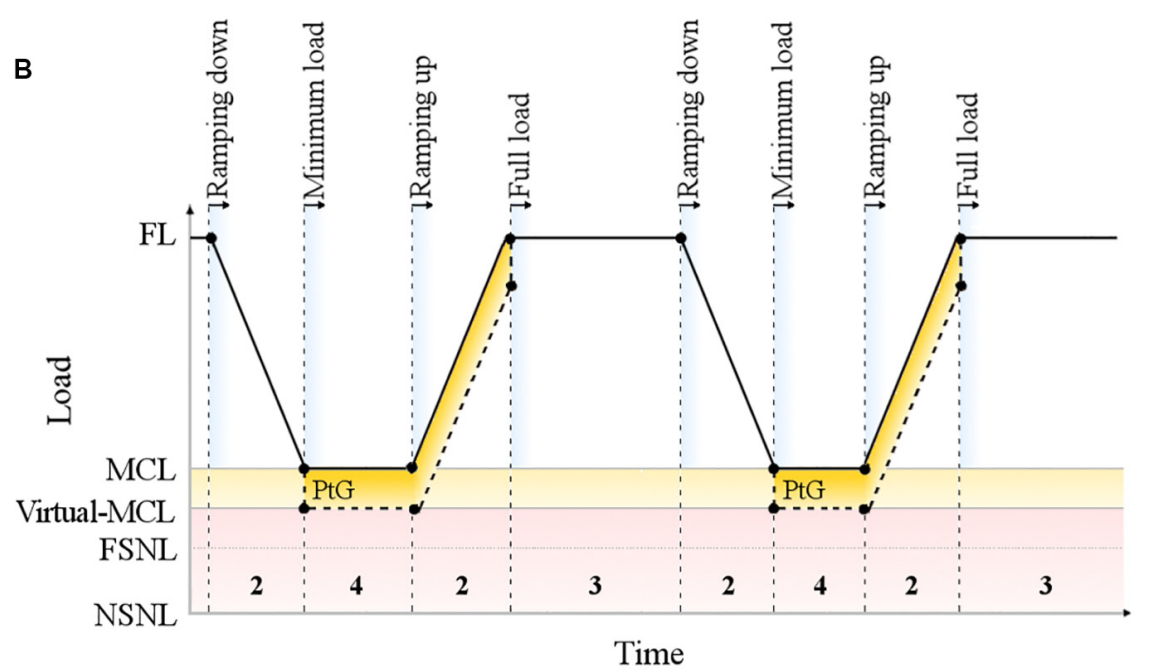

FIGURE 4 | Comparison between (A) conventional combined cycle power plant (CCPP) and (B) PtG-assisted CCPP while satisfying a peak of demand that takes place in the middle of a dispatch below the minimum complaint load.

the electrolyzer cost, between 500 (Schiebahn et al., 2015) and 1,200-2,000 €/kW $\mathrm{kW}_{\mathrm{e}}$ (Lee et al., 2019), and methanation reactor plus compressors (Schiebahn et al., 2015). Moreover, regarding methane storage, the following assumptions can be made. The longest shutdown considered is $48 \mathrm{~h}$, which corresponds to a storage of about 41.5 tons of methane (i.e., $576 \mathrm{MWh}$ ). The current commercial tanks for liquefied natural gas (LNG) are in the range of 30-50 tons (The Oxford Institute for Energy Studies, 2018; Linde, 2020), so we could even manage two to three consecutive 48-h shutdowns without emptying the tank. Therefore, the size proposed for our facility keeps within reasonable limits. In terms of cost, liquefaction plants range between 530 and 1,230 €/tpa (tons per annum) (The Oxford Institute for Energy Studies, 2018). As our plant requires a nominal capacity of liquefaction of $0.86 \mathrm{t} / \mathrm{h}$, the corresponding LNG plant would cost 6.8 M€ (assuming 7,500 operating hours and $1,060 € /$ tpa for a conventional plant, although the liquefaction process in the PtG plant would operate much less hours). Thus, this cost is considered to be already included in the total cost of the PtG plant, which amounts to $104 \mathrm{M} €$.

TABLE 2 | Performance of a 400-MWe combined cycle power plant vs. load.

\begin{tabular}{|c|c|c|c|}
\hline Load factor (\%) & $\begin{array}{c}\text { Thermal } \\
\text { efficiency gross } \\
\text { (\%) }\end{array}$ & $\begin{array}{c}\text { Natural gas input } \\
\text { power }\left(\mathrm{MW}_{\mathrm{th}}\right)\end{array}$ & $\begin{array}{c}\text { Specific } \mathrm{CO}_{2} \\
\text { emissions } \\
\left(\mathrm{kg}_{\mathrm{CO}_{2}} / \mathrm{MWh}\right)\end{array}$ \\
\hline 100 & 58.42 & 684.7 & 337.7 \\
\hline 90 & 57.85 & 622.3 & 341.0 \\
\hline 80 & 56.73 & 564.1 & 347.8 \\
\hline 70 & 55.07 & 508.5 & 358.3 \\
\hline 60 & 52.86 & 454.0 & 373.2 \\
\hline 50 & 50.11 & 399.1 & 393.7 \\
\hline 40 & 46.82 & 341.8 & 421.4 \\
\hline 30 & 42.98 & 279.2 & 459.0 \\
\hline
\end{tabular}


Regarding operation costs, fixed OPEX, fuel cost, and shutdowns are considered (Equation 4). Fixed OPEX is set at 25,000 €/MW $\mathrm{e} / \mathrm{y}$ (ACIL Tasman, 2009). Fuel cost (natural gas) is valued at $25 € / \mathrm{MWh}_{\mathrm{e}}$, according to $\mathrm{BP}$ annual report and Netherlands market (BP Statistical Review of World Energy, 2019). Shutdowns are estimated at 14,000, 22,000, and 32,000 $€$ for hot, warm, and cold start-ups, respectively (Kumar et al., 2012). The lifetime of the plant is assumed to be 25 years.

$$
\operatorname{OPEX}\left[\frac{C}{h}\right]=\text { fixed OPEX }\left[\frac{C}{h}\right]+\text { fuel costs }\left[\frac{C}{h}\right]
$$

Thus, the specific cost of producing electricity is calculated by adding the OPEX and the CAPEX, distributed throughout 25 years. This electricity production cost ranges from 48.5 $€ / \mathrm{MWh}_{\mathrm{e}}$ (full load) to $72.1 € / \mathrm{MWh}_{\mathrm{e}}$ (MCL); for this reason, the electricity price has been set at $65 € / \mathrm{MWh}$. With lower values, installation is not feasible as the production costs would be higher than the selling price. This value has no important relevance because it also affects the reference case, and in every case, there is a reduction in the electricity production cost. Evidently, electricity price varies considerably throughout the time of day and country, but it is out of the scope of this first analysis to deal with every possibility of price, depending if the power-togas installation is in operation or not. We considered to isolate the effect of variable pool prices from the effect of the proposed idea. In Table 3, all the technical and economic data used in the model to calculate these values are gathered.

\section{RESULTS}

In this section, each conventional shutdown is compared with the continuous operation at MCL through the utilization of the

\begin{tabular}{|c|c|c|}
\hline Variable & Value & References \\
\hline \multicolumn{3}{|l|}{ Technical } \\
\hline Gross power plant output $\left(\mathrm{MW}_{\mathrm{e}}\right)$ & 400 & \\
\hline Ancillaries consumption (\%) & 2.5 & \\
\hline Net power plant output $\left(\mathrm{MW}_{\mathrm{e}}\right)$ & 390 & \\
\hline Power to gas capacity $\left(\mathrm{MW}_{\mathrm{e}}\right)$ & 40 & \\
\hline Electrolyzer efficiency (\%) & 75 & Matute et al., 2019 \\
\hline \multicolumn{3}{|l|}{ Economic } \\
\hline CAPEX power plant $\left(€ / k W_{e}\right)$ & 800 & $\begin{array}{l}\text { Nalbandian-Sugden, } \\
2016\end{array}$ \\
\hline CAPEX power to gas $\left(€ / k W_{e}\right)$ & 2,600 & Schiebahn et al., 2015 \\
\hline Fixed OPEX (€/MW $\left.\mathrm{M}_{\mathrm{e}} / \mathrm{y}\right)$ & 25,000 & ACIL Tasman, 2009 \\
\hline \multicolumn{3}{|l|}{ Shutdown cost $(€)$} \\
\hline Hot start-up & 14,000 & Kumar et al., 2012 \\
\hline Warm start-up & 22,000 & Kumar et al., 2012 \\
\hline Cold start-up & 32,000 & Kumar et al., 2012 \\
\hline Natural gas price $\left(€ / \mathrm{MWh}_{\text {th }}\right)$ & 25 & $\begin{array}{c}\text { BP Statistical Review of } \\
\text { World Energy, } 2019\end{array}$ \\
\hline Electricity price (€/MWh & 65 & $\begin{array}{l}\text { Eurostat Statistics } \\
\text { Explained, } 2019\end{array}$ \\
\hline
\end{tabular}

power-to-gas storage system. The technical and the economic results are gathered in Tables 4-8 for shutdowns of 6-, 12-, and 48 -h duration in time frames of 24,48 , and $96 \mathrm{~h}$, respectively.

\section{Scenarios 1 and 2: Hot Start-Up}

For the reference case of short shutdown $(6 \mathrm{~h})$, a small economic loss is obtained with a specific cost of electricity at $65.44 € / \mathrm{MWh}$ and $\mathrm{CO}_{2}$ emissions at $4 \%$ above under full-load conditions. When the PtG system operates and the plant load is kept at minimum complaint load (30\%), the profit is not significant and the specific cost of electricity is very similar to that obtained in the reference case. Total and specific emissions of $\mathrm{CO}_{2}$ increase to 13.3 and $5.8 \%$, respectively, due to the higher consumption of fuel and the lower energy efficiency.

If the PtG storage system remains in operation, the trend drastically changes as plant load is raised up to 50 or $70 \%$. Specific $\mathrm{CO}_{2}$ emissions diminish with regards the previous case (scenario $2 \mathrm{a})$, being just $2 \%$ above the reference case for scenario $2 \mathrm{c}(70 \%$ $\mathrm{FL}$ ). An important economic improvement is achieved as the net benefit now becomes positive and increases with load, reaching a marginal profit of roughly 700 and $1,400 € / \mathrm{h}$, respectively. The specific cost of electricity decreases by more than 2 and $4 € / \mathrm{MWh}$ with respect to the reference scenario, which means a reduction of 3.4 and $6.6 \%$, respectively. In all cases, the cumulative effect of the number of cycles incurred by the turbine and the heat recovery steam generator could be significant in cases of shutdowns and start-ups. This concept would certainly reduce the O\&M costs of the combined cycle. From a cautious point of view, calculations do not consider this savings.

The respective marginal profits are above 16,000 and $34,000 €$, respectively, per avoided shutdown for a period of $24 \mathrm{~h}$. The significant increase in electricity sale incomes transforms the conventional shutdown situation with economic losses into a profitable operation. It has to be noted that the economic improvement of the alternative modes of operation (continuous MCL via PtG) is not directly related to the stored energy but to the avoidance of shutdown itself.

\section{Scenarios 3 and 4: Warm Start-Up}

In reference scenario 3, warm start-up with an outage period of $24 \mathrm{~h}$ is analyzed in a time frame of $48 \mathrm{~h}$. Unlike what happened in scenario 1 , the losses are now significant, with a negative net profit above $91,000 €$. While the $\mathrm{CO}_{2}$ emissions are quite similar, the specific cost of electricity increases up to $75.66 € / \mathrm{MWh}$, being $16 \%$ higher than that for hot start-up.

If the PtG system operates with minimum complain plant load $(30 \%)$, the net profit is even more negative than in scenario 3 , while the specific cost of electricity is slightly lower. The marginal profit with respect to the reference scenario is negative in this case $(-119 € / \mathrm{h})$. Total and specific emissions of $\mathrm{CO}_{2}$ increase to 42.9 and $14.5 \%$, respectively, due to the higher consumption of fuel and a drop in energy efficiency of seven percentage points (pp).

Nevertheless, the outlook changes if the plant load increases (scenarios 4b-4c). Energy efficiency improves to 2 pp for $50 \%$ part-load operation and 2 pp more for $70 \%$ part-load with regards scenario $4 \mathrm{a}$. Specific emissions decrease but are still 10 and 6\% above the reference case, respectively. The economic results are 
TABLE 4 | Conventional combined cycle power plant (CCPP) vs. PtG-assisted CCPP; hot start-up.

\begin{tabular}{|c|c|c|c|c|c|}
\hline \multirow[t]{2}{*}{ Summary of results } & & \multicolumn{4}{|c|}{ Reference 24 h } \\
\hline & & $\begin{array}{c}\text { Scenario } 1 \\
\text { Reference Hot } 6 \mathrm{~h}\end{array}$ & $\begin{array}{c}\text { Scenario 2a PtG } \\
\text { hot } 6 \text { h Load } 30 \%\end{array}$ & $\begin{array}{c}\text { Scenario 2b PtG } \\
\text { hot } 6 \text { h Load } 50 \%\end{array}$ & $\begin{array}{c}\text { Scenario 2c PtG } \\
\text { hot } 6 \text { h Load } 70 \%\end{array}$ \\
\hline Input natural gas & $\mathrm{MWh}_{\text {th }}$ & $11,513.58$ & $13,044.85$ & $14,004.13$ & $14,879.00$ \\
\hline Output energy & $\mathrm{MWh}_{\mathrm{e}}$ & $6,474.00$ & $6,936.00$ & $7,560.00$ & $8,184.00$ \\
\hline Energy efficiency & $\%$ & 56.2 & 53.2 & 54.0 & 55.0 \\
\hline Total costs & $€$ & $423,661.07$ & $452,930.19$ & $477,775.40$ & $500,434.55$ \\
\hline $\mathrm{CO}_{2}$ emissions & $\mathrm{tCO}_{2}$ & $2,271.40$ & $2,573.49$ & $2,762.73$ & 2, 935.33 \\
\hline Specific $\mathrm{CO}_{2}$ emissions & $\mathrm{kg} \mathrm{CO} / \mathrm{MWh}$ & 350.85 & 371.03 & 365.44 & 358.67 \\
\hline Specific electricity cost & $€ / \mathrm{MWh}$ & 65.44 & 65.30 & 63.20 & 61.15 \\
\hline Energy, PtG & MWh & & 240.00 & 240.00 & 240.00 \\
\hline $\mathrm{CH}_{4}$ energy storage & MWh & & 144.00 & 144.00 & 144.00 \\
\hline Cost increment & $€$ & & $29,269.12$ & $54,114.33$ & $76,773.47$ \\
\hline Electricity increment & $\mathrm{MWh}_{\mathrm{e}}$ & & 462.00 & $1,086.00$ & $1,710.00$ \\
\hline Additional electricity cost & $€ / M W h$ & & 63.35 & 49.83 & 44.90 \\
\hline Income from electricity (65€/MWh) & $€$ & $420,810.00$ & $450,840.00$ & $491,400.00$ & $531,960.00$ \\
\hline Profit & $€$ & $-2,851.07$ & $-2,090.19$ & $13,624.60$ & $31,525.45$ \\
\hline Marginal profit & $€$ & & 760.88 & $16,475.67$ & $34,376.53$ \\
\hline Marginal profit/hour & $€ / h$ & & 31.70 & 686.49 & $1,432.36$ \\
\hline
\end{tabular}

TABLE 5 | Conventional combined cycle power plant (CCPP) vs. PtG-assisted CCPP; warm start-up.

Summary of results

Reference $48 \mathrm{~h}$

\begin{tabular}{|c|c|c|c|c|c|}
\hline & & & & & \\
\hline & & $\begin{array}{c}\text { Scenario } 3 \\
\text { Reference Warm } \\
24 \mathrm{~h}\end{array}$ & $\begin{array}{c}\text { Scenario } 4 a \\
\text { Warm } 12 \text { h Load } \\
30 \%\end{array}$ & $\begin{array}{c}\text { Scenario } 4 b \\
\text { Warm } 12 \text { h Load } \\
50 \%\end{array}$ & $\begin{array}{c}\text { Scenario } 4 \mathrm{c} \\
\text { Warm } 12 \mathrm{~h} \text { Load } \\
70 \%\end{array}$ \\
\hline Input natural gas & $M W h_{\text {th }}$ & $15,216.28$ & $21,746.86$ & $24,864.50$ & $27,707.83$ \\
\hline Output energy & $\mathrm{MWh}_{\mathrm{e}}$ & $8,541.00$ & $10,662.00$ & $12,690.00$ & $14,718.00$ \\
\hline Total costs & $€$ & $646,238.52$ & $789,820.90$ & $870,567.83$ & $944,210.05$ \\
\hline $\mathrm{CO}_{2}$ emissions & $\mathrm{tCO}_{2}$ & 3,001.87 & 4, 290.22 & 4, 905.27 & $5,466.20$ \\
\hline Specific $\mathrm{CO}_{2}$ emissions & $\mathrm{kg} \mathrm{CO} / \mathrm{MWh}$ & 351.47 & 402.38 & 386.55 & 371.40 \\
\hline Specific electricity cost & $€ / \mathrm{MWh}$ & 75.66 & 74.08 & 68.60 & 64.15 \\
\hline Energy PtG & MWh & & 480.00 & 480.00 & 480.00 \\
\hline $\mathrm{CH}_{4}$ energy storage & MWh & & 288.00 & 288.00 & 288.00 \\
\hline Cost increment & $€$ & & $143,582.38$ & $224,329.31$ & $297,971.53$ \\
\hline Electricity increment & $\mathrm{MWh}_{\mathrm{e}}$ & & $2,121.00$ & 4, 149.00 & $6,177.00$ \\
\hline Additional electricity cost & $€ / M W h$ & & 67.70 & 54.07 & 48.24 \\
\hline Income from electricity (65€/MWh) & $€$ & $555,165.00$ & 693, 030.00 & $824,850.00$ & $956,670.00$ \\
\hline Profit & $€$ & $-91,073.52$ & $-96,790.90$ & $-45,717.83$ & $12,459.95$ \\
\hline Marginal profit & $€$ & & $-5,717.38$ & 45, 355.69 & $103,533.47$ \\
\hline Marginal profit/hour & $€ / h$ & & -119.11 & 944.91 & 2, 156.95 \\
\hline
\end{tabular}

now positive. The specific cost of electricity shows a reduction of 9 and 15\%, respectively. In spite of the negative net profit for scenario 4b, marginal profit is positive in both cases: 945 and $2,157 €$ per hour, respectively, which means total marginal profits of 45,000 and $103,000 €$ in the reference time framework of $48 \mathrm{~h}$. These figures are 38 and 50\% higher than those corresponding to the hot start-up.

As in the previous analysis, the economic improvement under the last two scenarios with continuous operation via $\mathrm{PtG}$ is not directly related to synthetic methane production but to the avoidance of shutdown itself.

\section{Scenarios 6 and 7: Cold Start-Up}

In reference scenario 6 , long outages of $48 \mathrm{~h}$ related to cold startups are assessed within a total time frame of $96 \mathrm{~h}$. The energy efficiency is similar to scenarios 1 and 3 , while specific $\mathrm{CO}_{2}$ emissions are slightly lower due to the different time intervals considered. The specific cost of electricity is $73.83 € / \mathrm{MWh}$, being $13 \%$ higher than that for the hot start-up. As it occurs in scenario 3 , the losses are very important, with a negative net profit above $155,000 €$.

When the PtG system is included in the analysis with minimum complain plant load (30\%), the net profit is even 
TABLE 6 | Conventional combined cycle power plant (CCPP) vs. PtG-assisted CCPP; cold start-up.

\begin{tabular}{|c|c|c|c|c|c|}
\hline \multirow[t]{2}{*}{ Summary of results } & & \multicolumn{4}{|c|}{ Reference $96 \mathrm{~h}$} \\
\hline & & $\begin{array}{c}\text { Scenario } 6 \\
\text { Reference Cold } \\
48 \mathrm{~h}\end{array}$ & $\begin{array}{l}\text { Scenario } 7 a \text { Cold } \\
48 \text { h Load } 30 \%\end{array}$ & $\begin{array}{l}\text { Scenario } 7 b \text { Cold } \\
48 \text { h Load } 50 \%\end{array}$ & $\begin{array}{l}\text { Scenario } 7 c \text { Cold } \\
48 \text { h Load } 70 \%\end{array}$ \\
\hline Input natural gas & $M \mathrm{Mh}_{\text {th }}$ & $31,243.52$ & $44,304.69$ & $50,300.16$ & $55,768.10$ \\
\hline Output energy & $\mathrm{MWh}_{\mathrm{e}}$ & $17,628.00$ & $21,870.00$ & $25,770.00$ & $29,670.00$ \\
\hline Total costs & $€$ & $1,301,481$ & $1,607,765$ & $1,763,048$ & $1,904,667$ \\
\hline $\mathrm{CO}_{2}$ emissions & $\mathrm{t} \mathrm{CO}_{2}$ & $6,163.7$ & $8,740.43$ & $9,923.21$ & $11,001.93$ \\
\hline Specific $\mathrm{CO}_{2}$ emissions & $\mathrm{kg} \mathrm{CO} / \mathrm{MWh}$ & 349.66 & 399.65 & 385.07 & 370.81 \\
\hline Specific electricity cost & $€ / \mathrm{MWh}$ & 73.83 & 73.51 & 68.41 & 64.20 \\
\hline Energy PtG & MWh & & 960.00 & 960.00 & 960.00 \\
\hline $\mathrm{CH}_{4}$ energy storage & MWh & & 576.00 & 576.00 & 576.00 \\
\hline Cost increment & $€$ & & $306,284.42$ & $461,566.98$ & $603,186.63$ \\
\hline Electricity increment & $\mathrm{MWh}_{\mathrm{e}}$ & & $4,242.00$ & $8,142.00$ & $12,042.00$ \\
\hline Additional electricity cost & $€ / \mathrm{MWh}$ & & 72.20 & 56.69 & 50.09 \\
\hline Income from electricity (65€/MWh) & $€$ & $1,145,820$ & $1,421,550$ & $1,675,050$ & $1,928,550$ \\
\hline Profit & $€$ & $-155,661$ & $-186,215$ & $-87,998$ & 23,882 \\
\hline Marginal profit & $€$ & & $-30,554$ & 67,663 & 179,543 \\
\hline Marginal profit/hour & $€ / h$ & & -318.28 & 704.82 & $1,870.24$ \\
\hline
\end{tabular}

TABLE 7 | Comparison of different operation modes during the period of warm start-up.

\begin{tabular}{|c|c|c|c|c|}
\hline \multirow[t]{2}{*}{ Summary of results } & & \multicolumn{3}{|c|}{ Reference $48 \mathrm{~h}$} \\
\hline & & $\begin{array}{c}\text { Scenario } 3 \text { Reference } \\
\text { Warm } 24 \text { h }\end{array}$ & $\begin{array}{c}\text { Scenario 4a Warm } \\
12 \text { h Load } 30 \%\end{array}$ & $\begin{array}{c}\text { Scenario } 5 \text { Warm } \\
12 \text { h Load 30-100\% }\end{array}$ \\
\hline Input natural gas & $\mathrm{MWh}_{\text {th }}$ & $15,216.28$ & $21,746.86$ & $26,900.68$ \\
\hline Output energy & $\mathrm{MWh}_{\mathrm{e}}$ & $8,541.00$ & $10,662.00$ & $14,418.00$ \\
\hline Total costs & $€$ & $646,238.52$ & $789,820.90$ & $923,298.42$ \\
\hline $\mathrm{CO}_{2}$ emissions & $\mathrm{t} \mathrm{CO}_{2}$ & $3,001.87$ & $4,290.22$ & $5,306.96$ \\
\hline Specific $\mathrm{CO}_{2}$ emissions & $\mathrm{kg} \mathrm{CO} / \mathrm{MWh}$ & 351.47 & 402.38 & 368.08 \\
\hline Specific electricity cost & $€ / \mathrm{MWh}$ & 75.66 & 74.08 & 64.04 \\
\hline Energy PtG & MWh & & 480.00 & 480.00 \\
\hline $\mathrm{CH}_{4}$ energy storage & $\mathrm{MWh}$ & & 288.00 & 288.00 \\
\hline Cost increment & $€$ & & $143,582.38$ & $277,059.90$ \\
\hline Electricity increment & $\mathrm{MWh}_{\mathrm{e}}$ & & $2,121.00$ & $5,877.00$ \\
\hline Additional electricity cost & $€ / M W h$ & & 67.70 & 47.14 \\
\hline Income from electricity (65€/MWh) & $€$ & $555,165.00$ & $693,030.00$ & $937,170.00$ \\
\hline Profit & $€$ & $-91,073.52$ & $-96,790.90$ & $13,871.58$ \\
\hline Marginal profit & $€$ & & $-5,717.38$ & $104,945.10$ \\
\hline Marginal profit/hour & $€ / h$ & & -119.11 & $2,186.36$ \\
\hline
\end{tabular}

more negative than in scenario 6 , while the specific cost of electricity is very similar. The marginal profit with respect to the reference situation is negative for scenario $7 \mathrm{a}(-318 € / \mathrm{h})$. Total and specific emissions of $\mathrm{CO}_{2}$ increase to 42 and $14 \%$, respectively, due to the higher consumption of fuel and a drop in energy efficiency of $7 \mathrm{pp}$.

As presented for warm start-up, the results improve if plant load increases (scenarios 7b-7c). Energy efficiency improves by 2 pp for $50 \%$ part-load operation and 2 pp more for $70 \%$ partload with regards scenario $7 \mathrm{a}$. Specific emissions decrease but are still 10 and $6 \%$ above the reference case, respectively. The specific cost of electricity shows a reduction greater than 5 and 9
$€ / M W h$ at 50 and $70 \%$ part load, respectively. The marginal profit is positive in both cases: 705 and 1,870 € per hour, respectively, which means total marginal profits of 67,663 and $179,543 €$ per long shutdown avoided in the reference time framework of $96 \mathrm{~h}$. For scenarios $7 b$ and $7 c$, the total marginal profits are four and five times greater than the equivalent of hot start-up, respectively. As in the previous analysis, the economic improvement is mainly caused by the avoidance of shutdown itself.

\section{Sensitivity Analysis}

The study presented in the previous sections has compared the economic and the environmental impact of avoiding hot, 
warm, and cold shutdowns through the utilization of a powerto-gas energy storage system. From the results, it is deduced that the most influential and uncertain economic parameter to reach profitability is the evolution of electricity demanded to the power plant. This figure depends in principle on the variable renewable generation and the total electricity demand. However, it has to be noted that the required power generation to a particular unit also depends on the availability of the other thermal power plants. Facilities with lower MCL, as those with energy storage systems, have advantage over their competitors and reduce cycling and the number of generation outages. Furthermore, the power initially assigned to those thermal plants which is still available under low demand would be augmented by assuming the power assigned to other thermal plants that have to stop. Therefore, it is highly probable that the former will not have to operate at its MCL for long periods.
Given the principal uncertainties regarding market regulation and power demanded to the PtG-assisted power plant, this section presents a sensitivity analysis to assess the effect of ramping up and down during the analyzed time frameworks. Two additional scenarios are compared to previous cases in Tables 7, 8. Scenarios 5 and 8 show an alternative operation to the conventional warm and cold shutdowns gathered in scenarios 3 and 6. As it was illustrated in Figure 4, there is a transient increase in electricity demand that would hardly be assumed if the unit is off. On the contrary, the CCPP which is still working provides a fast response and can assume the required increase in load.

For scenario 5, the reference time period is still $48 \mathrm{~h}$ and full load is required for $12 \mathrm{~h}$ during the period in which the conventional power plant (without $\mathrm{PtG}$ ) undergoes an outage of $24 \mathrm{~h}$. The results are compared with the reference scenario 3 of warm start-up and with scenario $4 \mathrm{a}$ where $30 \%$ load is fixed. Energy efficiency and specific $\mathrm{CO}_{2}$ emissions reach intermediate

TABLE 8 | Comparison of different operation modes during the period of cold start-up.

\begin{tabular}{|c|c|c|c|c|}
\hline \multirow[t]{2}{*}{ Summary of results } & & \multicolumn{3}{|c|}{ Reference 96 h } \\
\hline & & $\begin{array}{c}\text { Scenario } 6 \text { Reference } \\
\text { Cold } 48 \mathrm{~h}\end{array}$ & $\begin{array}{l}\text { Scenario } 7 \text { a Cold } \\
48 \text { h Load } 30 \%\end{array}$ & $\begin{array}{c}\text { Scenario } 8 \text { Cold } 48 \mathrm{~h} \\
\text { Load } 30-100 \%\end{array}$ \\
\hline Input natural gas & $\mathrm{MWh}_{\text {th }}$ & $31,243.52$ & 44, 304.69 & $55,305.80$ \\
\hline Output energy & $\mathrm{MWh}_{\mathrm{e}}$ & $17,628.00$ & $21,870.00$ & $29,655.00$ \\
\hline Total costs & $€$ & $1,301,481.13$ & 1,607, 765.55 & 1, 892, 694.30 \\
\hline $\mathrm{CO}_{2}$ emissions & $\mathrm{t} \mathrm{CO}_{2}$ & $6,163.72$ & $8,740.43$ & $10,910.73$ \\
\hline Specific $\mathrm{CO}_{2}$ emissions & $\mathrm{kg} \mathrm{CO} / \mathrm{MWh}$ & 349.66 & 399.65 & 367.92 \\
\hline Specific electricity cost & $€ / \mathrm{MWh}$ & 73.83 & 73.51 & 63.82 \\
\hline Energy PtG & MWh & & 960.00 & 960.00 \\
\hline $\mathrm{CH}_{4}$ energy storage & $\mathrm{MWh}$ & & 576.00 & 576.00 \\
\hline Cost increment & $€$ & & $306,284.42$ & $591,213.17$ \\
\hline Electricity increment & $\mathrm{MWh}_{\mathrm{e}}$ & & $4,242.00$ & 12, 027.00 \\
\hline Additional electricity cost & $€ / M W h$ & & 72.20 & 49.16 \\
\hline Income from electricity (65€/MWh) & $€$ & $1,145,820.00$ & $1,421,550.00$ & $1,927,575.00$ \\
\hline Profit & $€$ & $-155,661.13$ & $-186,215.55$ & $34,880.70$ \\
\hline Marginal profit & $€$ & & $-30,554.42$ & $190,541.83$ \\
\hline Marginal profit/hour & $€ / h$ & & -318.28 & $1,984.81$ \\
\hline
\end{tabular}

TABLE 9 | Economical comparison by varying the size of the power-to-gas installation for hot (6 h) and cold (48 h): scenarios $2 \mathrm{c}$ and $7 \mathrm{c}$.

\begin{tabular}{|c|c|c|c|c|c|c|c|c|c|c|c|c|}
\hline & \multicolumn{7}{|c|}{ Hot 6 h; $70 \%$; scenario 2c } & \multicolumn{5}{|c|}{ Cold 24 h; 70\%; scenario 7c } \\
\hline & Reference Hot 6 h & $10 \mathrm{MW}$ & $20 \mathrm{MW}$ & $30 \mathrm{MW}$ & $40 \mathrm{MW}$ & $50 \mathrm{MW}$ & Reference Cold 24 h & $10 \mathrm{MW}$ & $20 \mathrm{MW}$ & $30 \mathrm{MW}$ & $40 \mathrm{MW}$ & $50 \mathrm{MW}$ \\
\hline $\begin{array}{l}\text { Input natural } \\
\text { gas }\end{array}$ & 11,514 & 14,987 & 14,951 & 14,915 & 14,879 & 14,843 & 31,244 & 56,632 & 56,344 & 56,056 & 55,768 & 55,480 \\
\hline Output energy & 6,474 & 8,364 & 8,304 & 8,244 & 8,184 & 8,124 & 17,628 & 31,110 & 30,630 & 30,150 & 29,670 & 29,190 \\
\hline Total costs & 423,661 & 503,232 & 502,299 & 501,367 & 500,435 & 499,502 & $1,301,481$ & $1,927,045$ & $1,919,586$ & $1,912,127$ & $1,904,668$ & $1,897,209$ \\
\hline Cost increment & & 79,571 & 78,638 & 77,706 & 76,773 & 75,841 & & 625,564 & 618,105 & 610,646 & 603,187 & 595,727 \\
\hline $\begin{array}{l}\text { Income from } \\
\text { electricity } \\
\text { (65€/MWh) }\end{array}$ & 420,810 & 543,660 & 539,760 & 535,860 & 531,960 & 528,060 & $1,145,820$ & $2,022,150$ & $1,990,950$ & $1,959,750$ & $1,928,550$ & $1,897,350$ \\
\hline Profit & $-2,851$ & 40,428 & 37,461 & 34,493 & 31,525 & 28,558 & $-155,661$ & 95,105 & 71,364 & 47,623 & 23,882 & 141 \\
\hline Marginal profit & & 43,279 & 40,312 & 37,344 & 34,377 & 31,409 & & 250,766 & 227,025 & 203,284 & 179,543 & 155,803 \\
\hline $\begin{array}{l}\text { Marginal } \\
\text { profit/hour }\end{array}$ & & 1,803 & 1,680 & 1,556 & 1,432 & 1,309 & & 2,612 & 2,365 & 2,118 & 1,870 & 1,623 \\
\hline
\end{tabular}


values: the former is $4.6 \mathrm{pp}$ above scenario $4 \mathrm{a}$, while the latter is $5 \%$ greater than the reference case. The improvement is significant from an economic point of view. The specific cost of electricity decreases almost $11 € / M W h$ and the marginal profit amounts to $105,000 €$ with respect to the reference case. Moreover, the net profit turns from negative to positive figures.

A similar trend is observed in Table 8 for the cold start-up situations. Scenario 8 consists in a reference time framework of $96 \mathrm{~h}$ and an outage period of $48 \mathrm{~h}$. During this period, the requested power suddenly increases up to $100 \%$ load during $24 \mathrm{~h}$. The results are compared with reference scenario 6 of cold start-up and with scenario 7a where load is fixed at MCL. Energy efficiency and specific $\mathrm{CO}_{2}$ emissions reach intermediate values. The efficiency is $4.3 \mathrm{pp}$ above scenario $7 \mathrm{a}$, while specific emissions increase to $5 \%$ regarding scenario 6 . The improvement is also relevant from an economic point of view. The specific cost of electricity decreases by $10 € / \mathrm{MWh}$ and the marginal profit amounts to $190,500 €$ with respect to the reference case. The net profit also becomes positive, being 2.5 times the benefit for warm start-up (scenario 5).

Another relevant variable that has to be analyzed in the sensitivity analysis is the power-to-gas size (electrolyzers plus methanation). As a reference case, $10 \%$ of the maximum load of the combined cycle was chosen for calculations in order to have enough flexibility to reduce the MCL and get the most of the operational hours in the power-to-gas installation. Table 9 presents the summary of some economic results when the size of the power to gas varies between 10 and $50 \mathrm{MW}$. It can be concluded that lower sizes of the power-to-gas system led to better economic results in both, avoiding hot and cold shutdowns and start-ups. When the installation size is reduced, it means that more power is available to be sold. As the electricity price is high, the extra incomes surpass the slight increment of total costs. The incremental profit compared with the reference case $(40 \mathrm{MW})$ is not a decisive quantity, around $5 \%$ in the case of scenario $7 \mathrm{c}$ and up to $20 \%$ in scenario $2 \mathrm{c}$ due to the low profit results in this case. Here the issue does not depend only on power to gas but also on the incremental flexibility of the combined cycle. For a single avoided stop, the economic results are better with low size of the system, but the flexibility gain is very limited and not enough to avoid the stop. The key variable is the incremental flexibility that determines the operational hours of the system and their feasibility. As it has been explained previously with the electricity prices, the casuistic is huge and specific studies have to be done in a case-by-case basis.

According to this study, important marginal profits, even net profit, can be achieved if combined cycle power plants utilize power-to-gas technology to avoid shutdowns and extend the capacity factor. The impact of cycling on energy efficiency is damped, but this measure entails a small increase in specific $\mathrm{CO}_{2}$ emissions.

\section{CONCLUSION}

The integration of a combined cycle and a power-to-gas energy storage system is proposed in this study to increase
CCPP flexibility of operation and improve economic results under energy systems with high shares of renewable energy sources. This combination allows for a virtual reduction of the minimum complaint load of the CCPP through the diversion of instantaneous excess electricity. The present case study analyses a $400-\mathrm{MW}_{\mathrm{e}}$ combined cycle with MCL of $30 \%$ that can be virtually reduced to $20 \%$ by means of a $40-\mathrm{MW}_{\mathrm{e}}$ PtG plant.

Eight scenarios were described to compare the reference case of conventional operation under hot, warm, and cold start-ups with power-to-gas-assisted operation. The results highlight that the hybrid system operating at MCL is not recommended for hot start-ups since the profit obtained is not significant in comparison to that of conventional operation. However, an increase in plant load operation of up to $50-70 \%$ dramatically modifies the trend, and a great reduction of specific $\mathrm{CO}_{2}$ emissions is found together with a significant economic improvement. The observed variation is related to the large increase in electricity sale incomes which transforms the conventional shutdown situation with economic losses into a profitable operation.

The economic losses under warm start-up conventional operation are significant and the net profit is strongly negative. The hybrid system of PtG-assisted operation at MCL is still not recommended since its net profits are even more negative. Increments of plant load may again modify this behavior and energy efficiency is improved in higher part-load operation, showing positive economic results. The obtained marginal profits indicate that the hybrid system with CCPP operating with part loads over $50 \%$ is profitable and thus recommended.

The behavior of the hybrid system for cold start-up is analogous to the one described for warm start-ups. The economic losses of the reference cold start-up case are very important and the inclusion of the PtG system with the CCPP operating at MCL leads to an even more negative net profit. As presented for warm start-up, the results for higher CCPP loads are much more advantageous with the positive marginal profits. For all the studied cases, the largest amount of economic improvement is related to the avoidance of shutdown.

The analysis of results has pointed out that the most relevant and uncertain economic parameter to reach profitability is the evolution of the amount of electricity demanded to the CCPP. This value is initially related to the variable RES generation and the total electricity demand. It must be highlighted that low electricity demand may remove other thermal power generators with higher MCL of the power pool and leave more room for the participation of our hybrid proposal. Therefore, facilities with lower (real or virtual) MCL present certain advantage over their competitors and reduce cycling and the number of generation outages. To assess these uncertainties related to market regulation and power demanded to the PtG-assisted power plant, several sensitivity analyses have been performed to determine the effect of change load during the time in which the combined cycle should be stopped and the effect of the size of the power-to-gas system. Conclusions in both cases reinforce the finding that the casuistic is huge and specific studies have to be done in a case-by-case basis to achieve detailed and reliable feasibility studies. 
According to the results obtained in this study, important marginal profits may be obtained when combined cycle power plants utilize power-to-gas technology to avoid shutdowns and extend the capacity factor. The impact of cycling on energy efficiency is avoided, but this measure entails a small increase in specific $\mathrm{CO}_{2}$ emissions. The use of biogas as source of $\mathrm{CO}_{2}$ for the methanation stage may contribute to balance carbon emissions (Allman et al., 2019; Anghilante et al., 2019). This option should be further investigated in future works because it would also increase the renewable share in the natural gas sector.

\section{DATA AVAILABILITY STATEMENT}

All datasets presented in this study are included in the article.

\section{AUTHOR CONTRIBUTIONS}

$\mathrm{MB}, \mathrm{BP}, \mathrm{PL}$, and LR: conceptualization. $\mathrm{MB}$ and LR: methodology. MB, BP, and PL: writing. BP and LR: results. BP and

\section{REFERENCES}

ACIL Tasman (2009). Fuel Resource, New Entry And Generation Costs In The NEM - Final Report. Sydney: ACIL Tasman.

Allman, A., Palys, M. J., and Daoutidis, P. (2019). Scheduling-informed optimal design of systems with time-varying operation: a wind-powered ammonia case study. Aiche J 65:16434. doi: 10.1002/aic.16434

Andika, R., Nandiyanto, A. B. D., Putra, Z. A., Bilad, M. R., Kim, Y., Yun, C. M., et al. (2018). Co-electrolysis for power-to-methanol applications. Renew. Sustain. Energy Rev. 95, 227-241. doi: 10.1016/j.rser.2018.07.030

Angelidaki, I., Treu, L., Tsapekos, P., Luo, G., Campanaro, S., Wenzel, H., et al. (2018). Biogas upgrading and utilization: current status and perspectives. Biotechnol. Adv. 36, 452-466. doi: 10.1016/j.biotechadv.2018.01.011

Anghilante, R., Müller, C., Schmid, M., Colomar, D., Ortloff, F., Spörl, R., et al. (2019). Innovative power-to-gas plant concepts for upgrading of gasification bio-syngas through steam electrolysis and catalytic methanation. Energy Convers. Manag. 183, 462-473. doi: 10.1016/j.enconman.2018.12.101

Baier, J., Schneider, G., and Heel, A. (2018). A cost estimation for $\mathrm{CO}_{2}$ reduction and reuse by methanation from cement industry sources in Switzerland. Front. Energy Res. 6:5. doi: 10.3389/fenrg.2018.00005

Bailera, M., Hanak, D. P., Lisbona, P., and Romeo, L. M. (2019a). Techno-economic feasibility of power to gas-oxy-fuel boiler hybrid system under uncertainty. Int. J. Hydro. Energy 44, 9505-9516. doi: 10.1016/j.ijhydene.2018.09.131

Bailera, M., Lisbona, P., Llera, E., Peña, B., and Romeo, L. M. (2019b). Renewable energy sources and power-to-gas aided cogeneration for non-residential buildings. Energy 181, 226-238. doi: 10.1016/j.energy.2019.05.144

Bailera, M., Lisbona, P., and Romeo, L. M. (2019c). Avoidance of partial load operation at coal-fired power plants by storing nuclear power through power to gas. Int. J. Hydro. Energy 44, 26063-26075. doi: 10.1016/j.ijhydene.2019.08.033

Bailera, M., Kezibri, N., Romeo, L. M., Espatolero, S., Lisbona, P., and Bouallou, C. (2017a). Future applications of hydrogen production and $\mathrm{CO}_{2}$ utilization for energy storage: hybrid power to gas-oxycombustion power plants. Int. J. Hydro. Energy 42:123. doi: 10.1016/j.ijhydene.2017.02.123

Bailera, M., Lisbona, P., Romeo, L. M., and Espatolero, S. (2017b). Power to gas projects review: lab, pilot and demo plants for storing renewable energy and $\mathrm{CO}_{2}$. Renew. Sustain. Energy Rev. 69, 292-312. doi: 10.1016/j.rser.2016. 11.130

Bailera, M., and Lisbona, P. (2018). Energy storage in Spain: forecasting electricity excess and assessment of power-to-gas potential up to 2050. Energy 143, 900-910. doi: 10.1016/j.energy.2017.11.069
PL: validation. MB: artwork. All authors contributed to the article and approved the submitted version.

\section{FUNDING}

The work described in this manuscript was supported by the $\mathrm{R}+\mathrm{D}$ Spanish National Program from Ministerio de Economía y Competitividad, MINECO (Spanish Ministry of Economy and Competitiveness) and the European Regional Development Funds (European Commission), under project ENE2016-76850R. This work was also supported by the Government of Aragon and co-financed by FEDER 2014-2020 "Construyendo Europa desde Aragón” (Research Group DGA T46_17R and project LMP134_18).

\section{ACKNOWLEDGMENTS}

We are thankful for the comments and advice given by the reviewers. They have improved the content of this work and pointed out some research directions of particular interest.

Becker, W. L., Penev, M., and Braun, R. J. (2019). Production of synthetic natural gas from carbon dioxide and renewably generated hydrogen: a technoeconomic analysis of a power-to-gas strategy. J. Energy Resour. Technol. Trans. ASME 141:021901. doi: 10.1115/1.4041381

BP Statistical Review of World Energy (2019). BP. Full Report - BP Statistical Review of World Energy. Available online at: https://www.bp.com/content/ $\mathrm{dam} / \mathrm{bp} /$ business-sites/en/global/corporate/pdfs/energy-economics/statisticalreview/bp-stats-review-2019-full-report.pdf

Brynolf, S., Taljegard, M., Grahn, M., and Hansson, J. (2018). Electrofuels for the transport sector: a review of production costs. Renew. Sustain. Energy Rev. 81, 1887-1905. doi: 10.1016/j.rser.2017.05.288

Buttler, A., and Spliethoff, H. (2018). Current status of water electrolysis for energy storage, grid balancing and sector coupling via power-to-gas and power-toliquids: a review. Renew. Sustain. Energy Rev. 82, 2440-2454. doi: 10.1016/j.rser. 2017.09.003

Capros, P., Vita, A., De Tasios, N., Siskos, P., Kannavou, M., Petropoulos, A., et al. (2016). EU Reference Scenario 2016: Energy, Transport And GHG Emissions. Trends to 2050. Brussels: European Union.

Chauvy, R., Dubois, L., Lybaert, P., Thomas, D., and De Weireld, G. (2020). Production of synthetic natural gas from industrial carbon dioxide. Appl. Energy 260:114249. doi: 10.1016/j.apenergy.2019.114249

Chen, S., Wei, Z., Sun, G., Wang, D., Zhang, Y., and Ma, Z. (2018). Stochastic lookahead dispatch for coupled electricity and natural-gas networks. Electr. Power Syst. Res. 164, 159-166. doi: 10.1016/j.epsr.2018.07.038

Colbertaldo, P., Agustin, S. B., Campanari, S., and Brouwer, J. (2019). Impact of hydrogen energy storage on California electric power system: towards $100 \%$ renewable electricity. Int. J. Hydro. Energy 44, 9558-9576. doi: 10.1016/j. ijhydene.2018.11.062

Cormos, A. M., Dinca, C., Petrescu, L., Andreea Chisalita, D., Szima, S., and Cormos, C. C. (2018). Carbon capture and utilisation technologies applied to energy conversion systems and other energy-intensive industrial applications. Fuel 211, 883-890. doi: 10.1016/j.fuel.2017.09.104

de Groot, M., Crijns-Graus, W., and Harmsen, R. (2017). The effects of variable renewable electricity on energy efficiency and full load hours of fossil-fired power plants in the European Union. Energy 138, 575-589. doi: 10.1016/J. ENERGY.2017.07.085

Di Salvo, M., and Wei, M. (2019). Synthesis of natural gas from thermochemical and power-to-gas pathways for industrial sector decarbonization in California. Energy 182, 1250-1264. doi: 10.1016/j.energy.2019. 04.212 
European Commission (2018). Directive (EU) 2018/2001 Of The European Parliament And Of The Council Of 11 December 2018 On The Promotion Of The Use Of Energy From Renewable Sources. Brussels: European Commission.

Eurostat Statistics Explained (2019). Eurostat. 2019. EU. Eurostat. Statistics Explained. Brussels: Eurostat.

Eveloy, V., and Gebreegziabher, T. (2018). A review of projected power-to-gas deployment scenarios. Energies 11:1824. doi: 10.3390/en11071824

Gahleitner, G. (2013). Hydrogen from renewable electricity: an international review of power-to-gas pilot plants for stationary applications. Int. J. Hydro. Energy 38, 2039-2061. doi: 10.1016/j.ijhydene.2012.12.010

Giglio, E., Lanzini, A., Santarelli, M., and Leone, P. (2015). Synthetic natural gas via integrated high-temperature electrolysis and methanation: part I-energy performance. J. Energy Storage 1, 22-37. doi: 10.1016/j.est.2015.04.002

Gilbert, A. Q., and Sovacool, B. K. (2017). Benchmarking natural gas and coalfired electricity generation in the United States. Energy 134, 622-628. doi: 10.1016/j.energy.2017.05.194

Gonzalez-Salazar, M. A., Kirsten, T., and Prchlik, L. (2018). Review of the operational flexibility and emissions of gas- and coal-fired power plants in a future with growing renewables. Renew. Sustain. Energy Rev. 82, 1497-1513. doi: 10.1016/J.RSER.2017.05.278

Götz, M., Lefebvre, J., Mörs, F., McDaniel Koch, A., Graf, F., Bajohr, S., et al. (2015). Renewable Power-to-Gas: a technological and economic review. Renew. Energy $85,1-20$.

He, G. X., Yan, H., Chen, L., and Tao, W. Q. (2020). Economic dispatch analysis of regional electricity-gas system integrated with distributed gas injection. Energy 201:117512. doi: 10.1016/j.energy.2020.117512

He, L., Lu, Z., Zhang, J., Geng, L., Zhao, H., and Li, X. (2018). Low-carbon economic dispatch for electricity and natural gas systems considering carbon capture systems and power-to-gas. Appl. Energy 224, 357-370. doi: 10.1016/j. apenergy.2018.04.119

Hentschel, J., Babić, U., and Spliethoff, H. (2016). A parametric approach for the valuation of power plant flexibility options. Energy Rep. 2, 40-47. doi: 10.1016/ J.EGYR.2016.03.002

Jensen, S. H., Graves, C., Mogensen, M., Wendel, C., Braun, R., Hughes, G., et al. (2015). Large-scale electricity storage utilizing reversible solid oxide cells combined with underground storage of $\mathrm{CO}_{2}$ and CH4. Energy Environ. Sci. 8, 2471-2479. doi: 10.1039/c5ee01485a

Kumar, N., Besuner, P., Lefton, S., Agan, D., and Hilleman, D. (2012). Power Plant Cycling Costs. National Renewable Energy Laboratory. Available online at: https://www.nrel.gov/docs/fy12osti/55433.pdf

Lee, B., Lee, H., Heo, J., Moon, C., Moon, S., and Lim, H. (2019). Stochastic technoeconomic analysis of $\mathrm{H} 2$ production from power-to-gas using a high-pressure PEM water electrolyzer for a small-scale $\mathrm{H} 2$ fueling station. Sustain Energy Fuels 3, 2521-2529. doi: 10.1039/c9se00275h

Lew, D., Brinkman, G., Kumar, N., Lefton, S., Jordan, G., and Venkataraman, S. (2013). "Finding flexibility. cycling the conventional Fleet," in Proceedings of the IEEE Power Energy Magazine, Piscataway, NJ.

Lewandowska-Bernat, A., and Desideri, U. (2018). Opportunities of power-to-gas technology in different energy systems architectures. Appl. Energy 228, 57-67. doi: 10.1016/j.apenergy.2018.06.001

Linde (2020). Natural Gas Filling Station 2020. Dublin: Linde.

Lisbona, P., Frate, G. F., Bailera, M., and Desideri, U. (2018). Power-to-gas: analysis of potential decarbonization of spanish electrical system in long-term prospective. Energy 159, 656-668. doi: 10.1016/J.ENERGY.2018.06.115

Matute, G., Yusta, J. M., and Correas, L. C. (2019). Techno-economic modelling of water electrolysers in the range of several MW to provide grid services while generating hydrogen for different applications: a case study in Spain applied to mobility with FCEVs. Int. J. Hydro. Energy 44, 17431-17442. doi: 10.1016/j.ijhydene.2019.05.092

Nalbandian-Sugden, H. (2016). Operating Ratio And Cost Of Coal Power Generation. London: IEA Clean Coal Centre.

Naval, N., Sánchez, R., and Yusta, J. M. (2020). A virtual power plant optimal dispatch model with large and small-scale distributed renewable generation. Renew. Energy 151, 57-69. doi: 10.1016/j.renene.2019.10.144
Pierre, I., Bauer, F., Blasko, R., Dahlback, N., Dumpelmann, M., Kainurinne, K., et al. (2011). Flexible Generation: Backing Up Renewables. Available online at: https://www.google.com/url?sa=t\&rct=j\&q=\&esrc=s\&source=web\&cd= \&ved=2ahUKEwjv-IKvu7vqAhWJohQKHYWICFkQFjAAegQIAxAB\&url= https\%3A\%2F\%2Fwww3.eurelectric.org\%2FDownload\%2FDownload.aspx\% 3FDocumentFileID\%3D71337\&usg=AOvVaw3Idw040czr6Pa6RLx3uqsy

Romeo, L. M., Peña, B., Bailera, M., and Lisbona, P. (2018). "Analysis of the influence of Power-to-Gas systems in cyclic performance of fossil fuel power plants. ECOS 2018," in Proceedingsof the 31st International Conference on Efficiency, Cost, Optimization, Simulation and Environmental Impact of Energy Systems, Braga.

Rosenfeld, D. C., Böhm, H., Lindorfer, J., and Lehner, M. (2020). Scenario analysis of implementing a power-to-gas and biomass gasification system in an integrated steel plant: a techno-economic and environmental study. Renew. Energy 147, 1511-1524. doi: 10.1016/j.renene.2019.09.053

Schemme, S., Samsun, R. C., Peters, R., and Stolten, D. (2017). Power-to-fuel as a key to sustainable transport systems - an analysis of diesel fuels produced from $\mathrm{CO}_{2}$ and renewable electricity. Fuel 205, 198-221. doi: 10.1016/j.fuel.2017. 05.061

Schiebahn, S., Grube, T., Robinius, M., Tietze, V., Kumar, B., and Stolten, D. (2015). Power to gas: technological overview, systems analysis and economic assessment for a case study in Germany. Int. J. Hydro. Energy 40, 4285-4294. doi: 10.1016/j.ijhydene.2015.01.123

Sjoerd Brouwer, A., Van Den Broek, M., Seebregts, A., and Faaij, A. (2015). Operational flexibility and economics of power plants in future low-carbon power systems. Appl. Energy 156, 107-128. doi: 10.1016/j.apenergy.2015.06.065

Smith, R. W., Polukort, P., Maslak, C. E., Jones, C. M., and Gardiner, B. D. (2020). GE Power Systems Advanced Technology Combined Cycles. Report from General Electric 592. Atlanta, GA: GE Power Systems.

The Oxford Institute for Energy Studies (2018). LNG Plant Cost Reduction 2014 18. Oxford: The Oxford Institute for Energy Studies.

Thema, M., Bauer, F., and Sterner, M. (2019). Power-to-Gas: electrolysis and methanation status review. Renew. Sustain. Energy Rev. 112, 775-787. doi: 10.1016/j.rser.2019.06.030

United Nations Framework Convention on Climate Change [UNFCCC] (2015). The Paris Agreement. New York, NY: UNFCCC.

Van den Bergh, K., and Delarue, E. (2015). Cycling of conventional power plants: Technical limits and actual costs. Energy Convers. Manag. 97, 70-77. doi: 10.1016/j.enconman.2015.03.026

Vandewalle, J., Bruninx, K., and D'haeseleer, W. (2015). Effects of large-scale power to gas conversion on the power, gas and carbon sectors and their interactions. Energy Convers. Manag. 94, 28-39. doi: 10.1016/j.enconman.2015. 01.038

Wang, X., Bie, Z., Liu, F., and Kou, Y. (2019). Robust dispatch for integrated electricity and natural gas system considering wind power uncertainty. Energy Proc. 159, 130-135. doi: 10.1016/j.egypro.2018. 12.030

Wulf, C., Linßen, J., and Zapp, P. (2018). Review of power-to-gas projects in Europe. Energy Proc. 155, 367-378. doi: 10.1016/j.egypro.2018.11.041

Yin, S., Zhang, S., Andrews-Speed, P., and Li, W. (2017). Economic and environmental effects of peak regulation using coal-fired power for the priority dispatch of wind power in China. J. Clean. Prod. 162, 361-370. doi: 10.1016/j. jclepro.2017.06.046

Conflict of Interest: The authors declare that the research was conducted in the absence of any commercial or financial relationships that could be construed as a potential conflict of interest.

Copyright $(2020$ Bailera, Peña, Lisbona and Romeo. This is an open-access article distributed under the terms of the Creative Commons Attribution License (CC BY). The use, distribution or reproduction in other forums is permitted, provided the original author(s) and the copyright owner(s) are credited and that the original publication in this journal is cited, in accordance with accepted academic practice. No use, distribution or reproduction is permitted which does not comply with these terms. 